\title{
Effect of Fresh Red radish Roots Juice on some Biomarker for hypertrophy of adipose tissue in Obese Rats
}

\author{
Shimaa F.A.E Ghozy ${ }^{1}$ and Rehab Ibrahim Tag Al Deen ${ }^{2}$ \\ ${ }^{1}$ Home Economics Dept., Faculty of Specific Education, Mansoura university, Egypt. \\ ${ }^{2}$ Home Economics Dept., Faculty of Specific Education, Zagazig University. Egypt.
}

\section{ABSTRACT}

$R$

ecently, red radish sparked much interest in health and nutrition. So this study aimed to clarify the effect of red radish roots juice on obese rats. The chemical analysis of the phenolic content and antioxidant activity of the red radish roots juice were determined. An experiment performed on 36 male rats distributed into 6 equal groups. The first group kept as normal control, fed on a basal diet. While other groups fed on a high-fat diet to induce obesity. Obese rats, group (2) left as a positive control. Three obese groups (3, 4 and 5) received red radish roots juice (1, 2 and $3 \mathrm{ml} / \mathrm{kg}$ BW/ day) with a high fat-diet. After 6 weeks, biological parameters (feed intake FI, bodyweight gain BWG, body mass index BMI, and Feed efficiency ratio FER) calculated, and biochemical analysis (serum leptin, adiponectin, oxidative stress, tumor necrosis factor-alpha (TNFa), total antioxidant capacity, and lipid profile) estimated. Results confirmed that a high level of ferric reducing antioxidant (FRAP) and total radicaltrapping antioxidant parameter (TRAP) in a positive control group. Red radish roots juice affected a significant decrease in leptin, adiponectin, TNF- $\alpha$, and total oxidant capacity, while increasing the total antioxidant capacity as compared to the positive control group. Also, lipid profile normalization showed in group 5 that received a high-fat diet plus $3 \mathrm{ml}$ red radish roots juice. Therefore, this study concluded that the consumption of red radish as a functional food for a delay may protect the risk of adipose tissue.

Key words: Adipose tissue, Red radish, Anti-inflammatory, Body mass index 


\section{INTRODUCTION}

Obesity is defined as excess adipose tissue and BMI value is higher than 30 . BMI is an indicator that measures weight compared to height. Excess fat tissue led to severe health consequences such as diabetes, high blood pressure, and high blood lipids. Obesity between $40 \%$ and $70 \%$ is due to different genetic factors, not environmental or lifestyle factors. As research in mice has shown, there are 5 genes linked to appetite, which lead to obesity (Beopoulos et al., 2009). These genes are also present in humans. Leptin is one of the main genetic factors in obesity. Obesity is one of the main risks of metabolic diseases due to chronic inflammation. Irregular production of inflammatory cytokines is known by excessive adipose tissue on humoral mediators derived from antiinflammatory adipose tissue (fatty acids such as adiponectin) to induce a condition referred to as insulin resistance. Recently, naturally occurring antioxidant components are instrumental in dismantling free radiation and protecting health (Gutiérrez and Perez 2017). No sufficient scientific proof for the antidiabetic, anti-obesity and anticholesterol activity of plants. However, plant products can improve not only glucose metabolism but also improves lipid metabolism, antioxidant status, and capillary function (Zhu et al., 2012).

Radish (Raphanus sativus) the family (Cruciferae) is a radical crop. It comes in a variety of colors including white, red, purple, or black, and inform. It can be long, cylindrical, or circular. It may be eaten raw, cooked, or pickled. The oil obtained from radish seeds is also used in several useful health applications. Red radish is one of the oldest known foods, used by the Pharaohs and Greece (Otsuki et al., 2004 and Tamura et al., 2010). Red radish contains many important vitamins and minerals (folic acid, anthocyanins; potassium, calcium, copper, iron, phosphorus, and zinc); 
fiber, and antioxidants components, these elements make it rich in many benefits including liver activation, detoxification, and protect the liver from cancer (Cheon and Kim 2014 and Anna et al., 2016). It also works on diuresis, regulating bile production; activating enzymes; lowering high blood pressure and cholesterol level; reducing hyperglycemia; sexual dysfunction; softening and moisturizing skin; strengthens and density bones; expels worms from the intestines and improves overall health (Pu Jing et al., 2014).

\section{MATERIALS AND METHODS}

\section{Materials: -}

Casein, vitamins, minerals, cellulose, starch purchased from a local distributor of (Sigma Chemical Co) Cairo, Egypt. Red radish (Raphanus raphanistrum subsp. Sativus L.) and tallow purchased from a local market. Adult male albino rats (Sprague- Dawley strain) $(\mathrm{n}=30$ rat $)$ weighting approximately $\quad\left(\begin{array}{lll}180 & \pm 5 & \text { g. })\end{array}\right.$ purchased from the Helwan Experimental Animals farm. Kits for blood analysis purchased from Gamma Trade Company, Dokki, Cairo, Egypt.

\section{Methods: -}

\section{Preparation of fresh red radish roots juice:}

Red radish roots were washed thoroughly with tap water and homogenized by a household blender. The juice collected using suction filtration through filter papers, then stored at $-20^{\circ} \mathrm{C}$ until used according to (Gyamfi, et al., 2011).

\section{Total antioxidant capacity}

Ferric reducing antioxidant power (FRAP) and total radicaltrapping antioxidant parameter (TRAP) assay determined in red radish extract according to (Pellegrini et al., 2003, Benzie and Strain, 1999 and Ghiselli et al., 1995). The TRAP and TEAC values expressed as micromoles of Trolox per $g$ of plant extract while FRAP values expressed as 
micromoles of $\mathrm{Fe} 2+$ equivalents per $\mathrm{g}$ of plant extract.

\section{HPLC analysis of polyphenols and flavonoids:}

$40 \mathrm{mg}$ of extract sample dissolved in acidified methanol (10 $\mathrm{mL}, 1 \%$ formic acid). The extract kept at $-20{ }^{\circ} \mathrm{C}$ in the dark. The content of the phenolic determined accordingly method of (Singleton and Rossi, 1965). The data were calculated according to (Zhishen, et al., 1999), and expressed as $\mathrm{mg}$ of catechin equivalents (CE) per gram of extract.

\section{Induction of obesity:}

Rats fed four weeks on basal diet according to (Reeves, et al., 1993) with some modification in fat content containing: casein 14\%, cellulose $5 \%$, vitamin mixture $1 \%$, mineral mixture $3.5 \%$, sucrose $10 \%$, (tallow $19 \%$ +soybean oil 1\%), 1cystine $\quad 0.18, \quad$ choline bitartratte $0.25 \%$ and the remainder is starch to induce obesity in rats (Liu, et al., 2010).

\section{Biological study:}

Thirty-six adult male SpragueDawley rats were fed on standard diet for one week for adaptation. Rats were randomly divided into five groups (6 rats each) as follow: group one was fed on basal diet only and kept as negative control group, while groups $(2,3,4 \& 5$ ( of rats $(n=28)$ were fed on high fat diet for four weeks to induce obesity. These rats were then divided into three groups, positive control group and three curative groups given red radish orally $1 \mathrm{ml}, 2 \mathrm{ml}$ and $3 \mathrm{ml}$ juice /Kg / BW / day respectively during the experimental period (6 weeks).

\section{Anthropometric measurements:}

The body weight of each animal was measured three times a week. The length of the animals was determined once a month by measuring distances (from the nose to anal) Jeyakumar et $\boldsymbol{a l}$., (2006). Body mass index (BMI) was estimated once after a month by the formula: 
$\mathrm{BMI}=$ Body mass $(\mathrm{g}) /[$ noseanal distances $(\mathrm{cm})]^{2}$

$$
\mathrm{LDL}=\mathrm{TC}-(\mathrm{HDL}+\mathrm{TG} / 5)
$$

During the experiment period, the quantities of diet, which consumed and / or wasted, were recorded every day. In addition, rat's weight was recorded weekly to determine feed intake (FI) and body weight gain (BWG) \% according to Chapman et al., (1959).

Biochemical analysis of serum:

Concentrations of serum leptin and adiponectin were measured according to (Beutler et al., 1985 and Yudkin, 2003) respectively. Serum "total antioxidants" and oxidant capacities and TNF- $\alpha$ were measured using standard spectrophotometric methods according to (Cao et al., 1993, Flohe and Gunzler, 1984 and Thorell, 1973), respectively. Serum TG, TC and HDL were determined according to (Fossati and Prencipe, 1982, Allain, 1974 and Burstein et al., 1970), respectively. Serum LDL value was calculated according to the equation of Friedwald et al., (1972).

Atherogenic Index $=$ (Total cholesterol / HDL-cholesterol) were calculated according to the equation of Golay et al., (1990).

\section{Statistical Analysis:}

The obtained data
statistically analyzed using computerized SPSS and analyzed by one-way ANOVA (Analysis of variance) test using Duncan's multiple range test and $\mathrm{p}<0.05$ was used to indicate significance between different groups (Snedecor and Cochran, 1967).

\section{RESULTS AND DISCUSSION}

The results of the antioxidant activity of red radish juice (Table 1) reveals that they have potent antioxidant activity that represented by FRAP $(1354.05 \mu \mathrm{mol} \mathrm{Fe}++/ g)$ and TRAP (732.20 $\mu \mathrm{mol} \mathrm{TE} / \mathrm{g})$ assays. These results are in agreement with the data obtained by Goyeneche, (2015) found that in red 
radish were FRAP $(1298.57 \mu \mathrm{mol}$ $\mathrm{Fe}++\mathrm{g})$ and TRAP $(632.72 \mu \mathrm{mol}$ $\mathrm{TE} / \mathrm{g})$.

The phytochemical screening of red radish method juice by HPLC analysis showed the presence of different phenolic compounds including gallic, pyrogallol, coumaric, catechin, caffeine, caffeic acid, vanillic and Protocatechuic acid compounds as indicated by the maximum absorption ( $\lambda \max / \mathrm{nm})$ and retention times (Rt/min) of the phenolic standards (Table 2). It was reported that the of red radish leaves and roots contained flavonoids, tannins, catechin, coumaric, vanillic caffeic acid, gallic, syringic, rutin and orotocatechuic acid which showed different pharmacological properties (Levine et al., 2010 and Im et al., 2018 and Yu et al., 2013). Tannins are the most antioxidants present in the human diet and they are involved in protection against degenerative diseases and oxidative stress, gallic acid showed potent antioxidant activity by preventing lipid per-oxidation (Goyeneche et al., 2015). Based on the obtained data, the red radish has antioxidant activity, related to the phenolic content which promoting possible health benefits; thus, it can serve as an excellent natural source of antioxidant agents.

Table (3) revealed that the differences in feed intake, body weight gain and body mass index (BMI) between rats belonging to different study groups were insignificant except for groups 4 and 5 which showed a significant reduction in feed intake in addition to significant decrease in body weight gain as well as the final BMI when compared to the untreated (+ve) group and curative group 3 . From such that it could be noticed that the positive group (+ve) feed showed a significant increase in body weight gain (BWG), FER and (BMI) when compared to the normal group. Also, red radish in the curry was reported to inhibit body weight and adipocyte hypertrophy in obese rats (Goyeneche et al., 2015). The major groups of bioactive 
components in selected herbs are flavonoids, carotenoids, and phenethylamine alkaloids.

The leptin hormone, adiponectin, TNF- $\alpha$, total antioxidant capacity and total oxidant capacity of control and all the experimental rats' groups are shown in Table (4). From the same table, it could be observed that the significant increase on the leptin, TNF- $\alpha$, and Total oxidant capacity levels of positive control comparing with normal control but adiponectin and total antioxidant capacity values that were the significant decrease. There is marked increase in adiponectin and total antioxidant capacity of treatment groups' while decreased in the level of leptin hormone of the same groups when compared to positive control group. In similar studies done by Zhao et al., (2008) and Haque et al., (2014) found that high fat diet raises a marked hypertrophy of brown and white adipose tissue. It seems that the effect of red radish powder on reducing leptin hormone is known to be due to its powerful antioxidant activities (Isabel, et al., 2018). Group 5 significantly has the highest adiponectin, total oxidant capacity, and total antioxidant capacity but it has the lowest Leptin and TNF- $\alpha$ compared to the other treatment groups' revision in the table (Table 4). Although the TNF- $\alpha$ level in groups 5 was found to be the lowest among the study groups, the reduction was significant when compared with (+ve) group. These results confirm the antioxidant effect of red radish juice. This effect may be due to certain chemical constituents such as polyphenols or terpens in red radish which possess good oxygen radical scavenging potential (Ferreira et al., 2011).

The lipids profile of all groups is shown in Table (5). It could be indicated that the positive control group has the highest significant in all parameters of lipid profile except HDL-C. Groups as anti-obesity have significant $(\mathrm{P}<$ 
$0.05)$ increases in serum levels of TC, TG, LDL-c, VLDL-c, and atherogenic index when compared with the normal group. However, a significant decrease in TC, TG, LDL-c, VLDL-c, and atherogenic index levels was observed for the groups' levels 3, 2 and $1 \mathrm{ml}$ of red radish juice when compared with a positive control group. The more prominent effect is observed in LDL-c which is a known triggering factor for coronary occlusion or its block. This can substantiate the cardio protective effect of red radish. This finding agrees with an earlier study by Tamura $e t \quad a l$, (2010) who reported that several isoflavone constituents in red radish. They are phytoestrogen, which parallel estradiol, affect the digestive system, prevent serotonin reuptake, and thus raise serotonin levels in redeeming clamps. Also, Goyeneche et al., (2015) reported that the red radish exhibited a marked reduction in the hepatic total cholesterol and triglyceride levels both in the presence and absence of dietary cholesterol; the reduction of triglyceride levels in the absence of dietary cholesterol was in a dose-dependent manner. Red radish contains fibers, an effect of reducing the percentage of lipids. Red radish contains powerful antioxidant compounds that protect against chronic diseases (Islam et al., 2013). It may protect LDL cholesterol from oxidation, block cyclooxygenase and lipid enzymes and prevent lipid peroxide. It contains a high percentage of potassium, which helps to regulate blood pressure in the body (Giordano et al., 2007, and Haque et al., 2014).

\section{CONCLUSION}

In conclusion according to the obtained results, it seems that red radish roots juice could induce inhibitory effects on inflammatory cytokines such as TNF- $\alpha$, and leptin in addition to resist in level. It also can improve the lipid profile, control and the total antioxidant capacity with relieving of the oxidative stress. Therefore, the consumption of red radish roots could be 
beneficial for the control of adipose tissue-associated complications.

\section{REFERENCES}

\section{Allain CC (1974):}

Quantitative-enzymatic colorimetric determination of total and HDL cholesterol in serum or plasma. Clin. Chem., 20: 470.

\section{Anna C; Capus A; Monnerat M;} Ribeiro LC; de Souza $W$ and Martins JL(2016):

Application of high-content image analysis for quantitatively estimating lipid accumulation in oleaginous yeasts with potential for use in biodiesel production. Bioresour. Technol. 203: 309-317.

\section{Benzie IFF and Strain JJ (1999):}

Ferric reducing/antioxidant power assay: Direct measure of total antioxidant activity of biological fluids and modified version for

simultaneous measurement of total antioxidant power and ascorbic acid concentration. Methods Enzymol. 299, 15-27. 54.

\section{Beopoulos A; Chardot $T$ and} Nicaud JM (2009):

Yarrowia lipolytica: a model and a tool to understand the mechanisms implicated in lipid accumulation. Biochimie 91: 692-696.

\section{Beutler B; Greenwald D and Hulmes JD (1985): \\ Identity of tumour necrosis factor and the macrophage- secreted factor cachectin. Nature, 316:552-554.}


Cao G; Alessio $\mathbf{H}$ and Cutler $\mathbf{R}$ (1993):

Oxygen-radical absorbance capacity assay for antioxidants. Free Radic. Biol. Med., 14:303-311.

Chapman DG; Castilla $R$ and Campbell JA (1959):

Evaluation of protein in food. Determination of protein and food efficiency ratio. Can. J. Biochem. Physio. I (37) : 679-686.

\section{Cheon CJ and Kim SY (2014):}

Antiadipogenic effects of red radish (Raphanus sativus L.) sprout extract in 3T3-L1 preadipocytes. J. Life Sci. 24: 1224-1230. 12. Vivarelli $F$, Canistro D,

Ferreira ES; Silva MA; Demonte $A$ and Neves VA (2011):

Soy $\beta$-conglycinin (7S globulin) reduces plasma and liver cholesterol in rats fed hypercholesterolemic diet. $J$. Med. Food. 14: 94-100.

Flohe L and Gunzler WA (1984):

Oxygen radicals in biological systems. Methods Enzymol., 105: 114-212.

Fossati P and Prencipe L (1982):

Serum triglycerides determined colorimetrically with an enzyme that produces hydrogen peroxide. Clin. Chem., 28: 2077-2080.

Friedewald WT; Levy RI and Frerickson DS (1972):

Estimation of the concentration of low-density lipoprotein cholesterol in plasma without use of the preparative ultracentrifuge. Clin. Chem., 18: 499-502.

Ghiselli A; Serafini M; Maiani G; Azzini $E$ and Ferro-Luzzi AA (1995):

Fluorescence-based method for measuring total plasma 
antioxidant capability. Free Radic. Biol. Med. 18, 29-36. of Functional Foods, 16, 2015, 256-264.
Golay A; Ferrara J; Felber J and Schneider H (1990):

Cholesterol lowering effect skim milk from immunized cows in hypercholesterolemic patients. Am J Clin Nutr.; 52(6):1014-9.

Goyeneche, R., Roura S., Ponce, A., Vega-Galvez, A., Ouispefuentes, I. and Uribe, E. (2015):

Chemical characterization and antioxidant capacity of red radish (Raphanus sativus L.) leaves and roots. Journal of Functional Foods. 16: 256- 264.

Goyeneche R; Roura S; Ponce A; Vega-Gálvez A; Quispe-Fuentes I; Uribe E and Di Scala K (2015): Chemical characterization and antioxidant capacity of red radish (Raphanus sativus L.) leaves and roots, Journal
Gutiérrez RM and Perez RL (2017):

Raphanus sativus (Radish): their chemistry and biology. Scientific World Journal 4: 811-837.

Gyamfi K; Sarfo DK; Nyarko BJ B; Akaho EKH; Serfor-Armah Y and Ampomah-Amoako E (2011):

Assessment of elemental content in the fruit of Graviola plant, Annona Muricata, from some selected communities in Ghana by instrumental neutron activation analysis. Food Science. Elixir Food Science 41 5671-5675.

Haque M; Islam J; Rahaman A; Selina FA; Rahman MA; Hasan $M$ and Hossain $S$ (2014):

Raphanus sativus ameliorates atherogenic lipid profiles in 
hypercholesterolemic rats and hypercholesterolemia associated peroxidative liver damage. $J$ of Advances in Chemistry. 23: 1385-1394.

Im, JS; Lee EH; Lee JN; Kim K D; Kim HY and Kim MJ (2018):

Sulforaphane and total Phenolics contents and antioxidant activity of radish according to enotype and cultivation location with different altitudes, Korean Journal of Horticulture Science Technology, 28(3), 335-342.

Isabel Huang-Doran; ChenYuZhang and AntonioVidal-Puig (2018):

Extracellular vesicles:

Novel mediators of cell communication in metabolic disease.

Trends

Endocrinology Metabolic. 28, (1): 3-18
Islam J; Nahar T; Uddin B; Ahmed M and Hossain S (2013):

Spectra of alternative therapies of hypercholesterolemia by dietary bioactives: emphasis on nutrigenomics of polyphenols. Inn. J. Food Sci., 1(1): 1-7

\section{Jeyakumar SM; Vajreswari A and} Giridharan NV (2006):

Chronic dietary vitamin A supplementation regulates obesity in an obese mutant WNIN/Ob rat model. Obesity 2006, 14:52-9.

\section{Levine LH; Bisbee PA; Richards} JT; Birmele MN; Prior RL; Perchonok M; Dixon M; Yorio N C; Stutte GW and Wheeler RM (2010):

Quality characteristics of the radish grown under reduced atmospheric pressure, Advances in Space Research, 41, 754-762. 
Liu KJ; Tso P; Xiong Y and Wang G (2010):

Antiobesity and antihyperglycemic effects of ginsenoside $\mathrm{Rb} 1$ in rats. Diabetes. 59:2505-12.

Otsuki, T., Matsufuji, H., Takeda, M., Toyoda, M., Goda, Y. (2004):

Acylated anthocyanins from red radish (Raphanus sativus L.). Phytochemistry 60: 7987.

\section{Pellegrini N; Serafini M; Colombi} B; Del-Rio D; Salvatore S; Bianchi $M$ and Brighenti F (2003): Total antioxidant capacity of plant foods, beverages and oils consumed in Italy assessed by three different in vitro assays. J. Nutr. 133, 2812-2819.

Pu Jing, Li-Hua Song, Shan-Qi Shen, Shu-Juan Zhao, Jie Pang, Bing-Jun Qian. (2014):

Characterization of

Phytochemicals and Antioxidant Activities of
Red Radish Brines during Lactic Acid Fermentation. Molecules 201 4, 19 (7), 9675-9688.

Reeves PG; Nielsen FH and Fahey GCJ (1993):

AIN-93 purified diets for laboratory rodents: final report of the American Institute of Nutrition ad hoc writing committee on the reformulation of the AIN 76A rodent diet. J. Nutr., 123:1939-1951.

Goyeneche R (2015):

Chemical characterization and antioxidant capacity of red radish (Raphanus sativus L.) leaves and roots. Journal of Functional Foods 16:256-264.

Vivarelli F; Canistro D; Sapone A; De Nicola GR; Babot Marquillas C; Iori R; Antonazzo IC; Gentilini F; and Paolini $M$ (2016): 
Raphanus sativus cv. Sango sprout juice decreases dietinduced obesity in Sprague Dawley rats and ameliorates related disorders. PLoS One 11: e0150913,P. 1-17

Singleton CL; and Rossi JA (1965):

\begin{tabular}{|c|c|}
\hline $\begin{array}{l}\text { Colorimetry } \\
\text { phenolics } \\
\text { phosphomolybdic- } \\
\text { phosphotungstic }\end{array}$ & $\begin{array}{l}\text { total } \\
\text { with }\end{array}$ \\
\hline $\begin{array}{lc}\text { reagents. } & A m . \\
\text { Viticult. } & 16,\end{array}$ & $\begin{array}{r}J . \quad \text { Enol. } \\
144-158 .\end{array}$ \\
\hline $\begin{array}{l}\text { Molecules 2012, } \\
52 .\end{array}$ & $17 \quad 10321$ \\
\hline
\end{tabular}

\section{Snedecor GW and Cochran WG} (1967):

Statistical Methods. 7th Ed., The Lowa State University Press., Ames, Lowa, U.S.A.

Tamura S; Tsuji K; Yongzhen P; Ohnishi - Kameyama M and Murakami N (2010):

Six new acylated anthocyanins from red radish (Raphanus sativus). Chem
Pharm Bull (Tokyo)

58:1259-1262.

\section{Thorell JI (1973):}

A cysteine-rich adipose tissue-specific secretory factor inhibits adipocyte differentiation. Scand. J. Lab. Invest., 31:187.

\section{Yu L; Perret J; Harris M; Wilson} $J$ and Haley $S$ (2013):

Antioxidant properties of bran extracts from "Akron" wheat grown at different locations. Journal of Agriculture and Food Chemistry, 51, 1566-1570

Yudkin JS (2003):

Adipose tissue, insulin action and vascular disease: inflammatory signals. Int. $J$. Obes. Relat. Metab. Disord. 27 Suppl 3: S25-28.

\section{Zhao H L; Harding SV; Marinangeli CP; Kim YS and Jones PJ (2008):}


Hypocholesterolemic and anti-obesity effects of saponins from Platycodon grandiflorum in hamsters fed atherogenic diets. $J$. Food Sci., 73:195-200.

\section{Zhishen J; Mengcheng T;} Jianming W (1999):

The determination of flavonoids contents in mulberry and their scavenging effects on superoxide radicals. Food Chem., 64, 555-559.

\section{Zhu Z; Zhang S; Liu H; Shen H;} Lin $X$ and Yang $F$ (2012): A multi-omic map of the lipidproducing yeast Rhodosporidium toruloides. Nat. Commun. 3: 1112. 
Table 1: Antioxidant activity of fresh red radish juice from roots

\begin{tabular}{|l|c|c|}
\hline Antioxidant assay & $\begin{array}{c}\text { FRAP } \\
(\boldsymbol{\mu m o l ~ F e + + / g ) ~}\end{array}$ & $\begin{array}{c}\text { TRAP } \\
(\boldsymbol{\mu m o l ~ T E} / \mathbf{g})\end{array}$ \\
\hline Red radish & 1354.05 & 732.20 \\
\hline
\end{tabular}

FRAP: Ferric reducing antioxidant TRAP: total radical-trapping antioxidant

Table 2: Phenolic standards and their correlation with the compounds of red radish juice

\begin{tabular}{|c|c|c|}
\hline phenolic compound & RT $/ \mathbf{m i n}$ & $\boldsymbol{\lambda} \mathbf{m a x} / \mathbf{n m}$ \\
\hline Gallic acid & 7.2 & $\mathbf{1 2 . 9 6}$ \\
\hline Pyrogallol & 8.3 & $\mathbf{5 1 . 4 7}$ \\
\hline Coumaric & 15.3 & $\mathbf{7 . 9 9}$ \\
\hline Catechin & 18.9 & $\mathbf{4 7 . 1 1}$ \\
\hline Caffeine & 14.5 & $\mathbf{7 1 . 2 1}$ \\
\hline Caffeic acid & 19.3 & $\mathbf{3 2 0 . 2 0}$ \\
\hline Vanillic acid & 20.1 & $\mathbf{2 0 8 . 1 6}$ \\
\hline Protocatechuic acid & 21.3 & $\mathbf{7 7 . 1 1}$ \\
\hline
\end{tabular}

(Rt/min): Retention times $(\lambda \max / \mathrm{nm})$ : Maximum absorption 
Table (3): Effect of different levels of red radish juice on body weight gain, feed intake, FER, and BMI of the experimental rats' groups

\begin{tabular}{|c|c|c|c|c|c|}
\hline Groups & \multirow{2}{*}{$\begin{array}{c}\text { Control } \\
\text { Group }\end{array}$} & \multirow{2}{*}{$\begin{array}{c}\text { Positive } \\
\text { group }\end{array}$} & \multicolumn{3}{|c|}{ Anti-obesity } \\
\cline { 4 - 6 } & & & Group 3 & Group 4 & Group 5 \\
Parameters & & $1 \mathrm{ml}$ & $\mathbf{2 ~ m l}$ & $\mathbf{3}$ ml \\
\hline Feed intake & $17.33 \pm$ & $16.55 \pm$ & $16.10 \pm$ & $15.65 \pm$ & $14.95 \pm$ \\
(g/d) & $1.21 \mathrm{a}$ & $1.18 \mathrm{a}$ & $1.61 \mathrm{~b}$ & $1.27 \mathrm{~b}$ & $1.41 \mathrm{~b}$ \\
\hline Body weight gain & $90.87 \pm$ & $130.62 \pm$ & $98.44 \pm$ & $95.41 \pm$ & $93.44 \pm$ \\
$(\mathbf{g})$ & $8.62 \mathrm{a}$ & $5.11 \mathrm{~d}$ & $6.61 \mathrm{~b}$ & $7.31 \mathrm{c}$ & $8.14 \mathrm{c}$ \\
\hline FER & $0.089 \pm$ & 0.099 & $0.085 \pm$ & $0.083 \pm$ & $0.061 \pm$ \\
& $0.008 \mathrm{a}$ & $0.006 \mathrm{~d}$ & $0.004 \mathrm{~b}$ & $0.002 \mathrm{c}$ & $0.003 \mathrm{c}$ \\
\hline BMI & 0.37 & 0.58 & 0.43 & 0.40 & 0.38 \\
\hline$(\mathbf{g m}) /(\mathbf{c m}) \mathbf{2}$ & & & & & \\
\hline
\end{tabular}

The values are expressed as mean \pm SEM ( $n=6$ rats). Average values in every row holding unlike superscript $(a, b, c)$ noted significant variation. Means with the same letter are insignificantly different 
Table (4): Effect of different levels of red radish juice on serum leptin, adiponectin, TNF- $\alpha$, total antioxidant capacity and total oxidant capacity of the experimental rats' groups

\begin{tabular}{|c|c|c|c|c|c|}
\hline & Control & Positive & & i-obesi & \\
\hline Parameters & & Оотер & $\begin{array}{c}\text { Group } 3 \\
\text { 1ml }\end{array}$ & $\begin{array}{c}\text { Group } 4 \\
2 \mathrm{ml}\end{array}$ & $\begin{array}{c}\text { Group } 5 \\
3 \mathrm{ml}\end{array}$ \\
\hline $\begin{array}{l}\text { Leptin } \\
(\mathrm{pg} / \mathrm{ml})\end{array}$ & $\begin{array}{c}2.83 \pm \\
0.1 \mathrm{c}\end{array}$ & $\begin{array}{l}7.98 \pm \\
0.31 \mathrm{a}\end{array}$ & $\begin{array}{l}5.63 \pm \\
0.066 \mathrm{a}\end{array}$ & $\begin{array}{l}4.05 \pm \\
0.11 \mathrm{~b}\end{array}$ & $\begin{array}{l}3.65 \pm \\
0.11 b\end{array}$ \\
\hline $\begin{array}{c}\text { Adiponectin } \\
(\mathbf{u} / \mathbf{m L})\end{array}$ & $\begin{array}{l}8.67 \pm \\
0.06 \mathrm{a}\end{array}$ & $\begin{array}{l}4.98 \pm \\
0.05 \mathrm{~d}\end{array}$ & $\begin{array}{l}5.45 \pm \\
0.04 b\end{array}$ & $\begin{array}{l}7.01 \pm \\
0.47 \mathrm{a}\end{array}$ & $\begin{array}{l}7.99 \pm \\
0.47 a\end{array}$ \\
\hline $\begin{array}{l}\text { TNF- } \alpha \\
(\mathrm{pg} / \mathrm{ml})\end{array}$ & $\begin{array}{l}3.18 \pm \\
0.11 \mathrm{~d}\end{array}$ & $\begin{array}{l}8.73 \pm \\
0.17 \mathrm{a}\end{array}$ & $\begin{array}{c}6.71 \pm \\
0.126 \mathrm{~b}\end{array}$ & $\begin{array}{l}4.36 \pm \\
0.05 \mathrm{bc}\end{array}$ & $\begin{array}{l}3.91 \pm \\
0.05 \mathrm{c}\end{array}$ \\
\hline $\begin{array}{l}\text { Total antioxidant } \\
\text { capacity }(\mathrm{mmol} / \mathrm{L})\end{array}$ & $\begin{array}{l}4.76 \pm \\
0.04 \mathrm{a}\end{array}$ & $\begin{array}{l}1.76 \pm \\
0.04 \mathrm{~d}\end{array}$ & $\begin{array}{l}2.94 \pm \\
0.013 c\end{array}$ & $\begin{array}{c}3.16 \pm \\
0.013 b\end{array}$ & $\begin{array}{l}4.04 \pm \\
0.013 a\end{array}$ \\
\hline $\begin{array}{c}\text { Total oxidant capacity } \\
(\mathrm{mmol} / \mathrm{L})\end{array}$ & $\begin{array}{l}3.26 \pm \\
0.012 \mathrm{a}\end{array}$ & $\begin{array}{c}0.235 \pm \\
0.01 d\end{array}$ & $\begin{array}{l}1.36 \pm \\
0.014 \mathrm{c}\end{array}$ & $\begin{array}{l}2.57 \pm \\
0.01 \mathrm{ab}\end{array}$ & $\begin{array}{l}2.89 \pm \\
0.01 \mathrm{a}\end{array}$ \\
\hline
\end{tabular}

The values are expressed as mean \pm SEM ( $\mathrm{n}=6$ rats). Average values in every row holding unlike superscript $(a, b, c)$ noted significant variation. Means with the same letter are insignificantly different 
Table (5): Effect of different levels of red radish juice on serum lipid profile of the experimental rats' groups

\begin{tabular}{|c|c|c|c|c|c|}
\hline Groups & Control & Positive & & obes & \\
\hline & & & $\begin{array}{c}\text { Group } 3 \\
1 \mathrm{ml}\end{array}$ & $\begin{array}{c}\text { Group } \\
2 \mathrm{ml}\end{array}$ & $\begin{array}{c}\text { Group } 5 \\
3 \mathrm{ml}\end{array}$ \\
\hline $\begin{array}{c}\text { TC } \\
(\mathrm{mg} / \mathrm{dl})\end{array}$ & $\begin{array}{r}77.30 \\
\pm 3.66 \mathrm{c}\end{array}$ & $\begin{array}{l}146.69 \\
\pm 4.98 \mathrm{a}\end{array}$ & $\begin{array}{l}110.28 \\
\pm 4.45 \mathrm{~b}\end{array}$ & $\begin{array}{c}89.67 \\
\pm 1.99 \mathrm{~b}\end{array}$ & $\begin{array}{c}79.19 \\
\pm 2.19 \mathrm{~b}\end{array}$ \\
\hline $\begin{array}{c}\text { TG } \\
(\mathrm{mg} / \mathrm{dl})\end{array}$ & $\begin{array}{c}81.84 \\
\pm 3.65 \mathrm{c}\end{array}$ & $\begin{array}{l}156.51 \\
\pm 3.69 \mathrm{a}\end{array}$ & $\begin{array}{l}98.44 \pm \\
6.61 \mathrm{~b}\end{array}$ & $\begin{array}{r}93.46 \\
\pm 2.55 \mathrm{~b}\end{array}$ & $\begin{array}{l}90.44 \pm \\
4.14 \mathrm{~b}\end{array}$ \\
\hline $\begin{array}{l}\text { HDL-C } \\
\text { (mg/dl) }\end{array}$ & $\begin{array}{r}41.75 \\
\pm 1.13 \mathrm{a}\end{array}$ & $\begin{array}{r}31.48 \\
\pm 1.87 \mathrm{c}\end{array}$ & $\begin{array}{c}37.92 \\
\pm 2.11 \mathrm{~b}\end{array}$ & $\begin{array}{r}39.45 \\
\pm 2.11 \mathrm{a}\end{array}$ & $\begin{array}{c}40.12 \\
\pm 2.11 \mathrm{a}\end{array}$ \\
\hline $\begin{array}{l}\text { LDL-C } \\
\text { (mg/dl) }\end{array}$ & $\begin{array}{c}28.59 \\
\pm 3.23 \mathrm{c}\end{array}$ & $\begin{array}{r}49.89 \\
\pm 5.67 \mathrm{a}\end{array}$ & $\begin{array}{r}39.88 \\
\pm 3.01 \mathrm{~b}\end{array}$ & $\begin{array}{r}34.48 \\
\pm 3.22 \mathrm{~b}\end{array}$ & $\begin{array}{c}30.11 \\
\pm 3.22 \mathrm{bc}\end{array}$ \\
\hline VLDL-C & $\begin{array}{c}12.84 \\
\pm 0.23 \mathrm{c}\end{array}$ & $\begin{array}{r}22.39 \\
\pm 013 a\end{array}$ & $\begin{array}{c}17.86 \\
\pm 0.24 \mathrm{~b}\end{array}$ & $\begin{array}{l}15.86 \\
0.28 b\end{array}$ & $\begin{array}{r}14.69 \\
\pm 0.23 \mathrm{~b}\end{array}$ \\
\hline AI & 2.00 & 4.00 & 3.51 & 2.28 & 2.28 \\
\hline
\end{tabular}

The values are expressed as mean \pm SEM ( $n=6$ rats).

Average values in every row holding unlike superscript $(a, b, c)$ noted significant variation. Means with the same letter are insignificantly different

TC: Total Cholesterol.

HDL-c: High density lipoprotein.

VLDL-c: Very low-density lipoprotein.
TG: Triglycerides

LDL-c: Low density lipoprotein.

AI: Atherogenic Index 


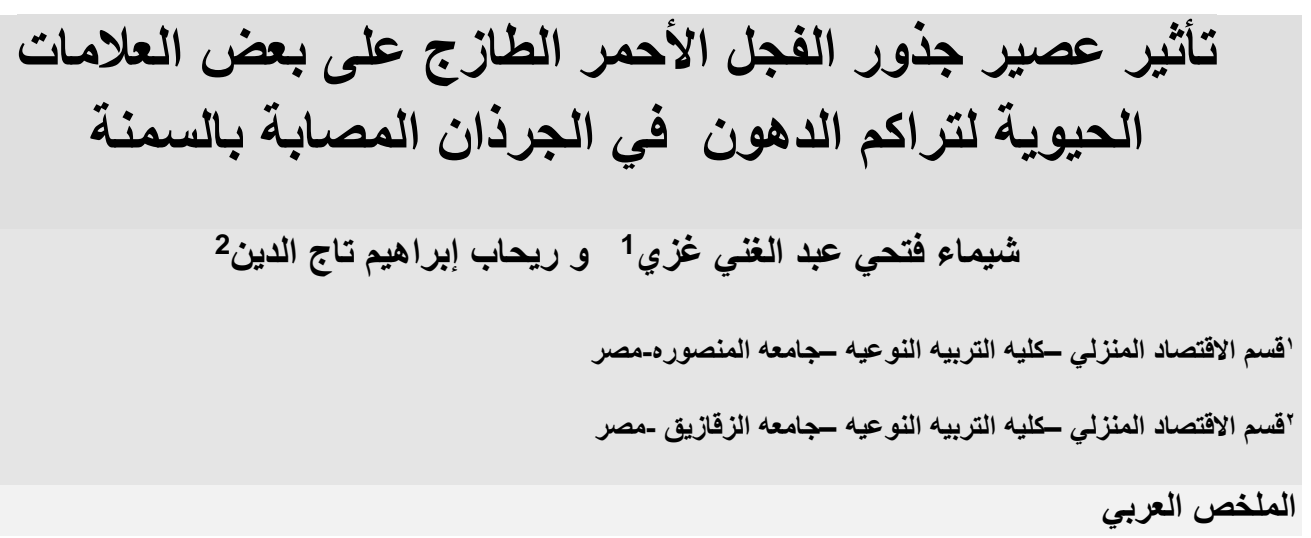

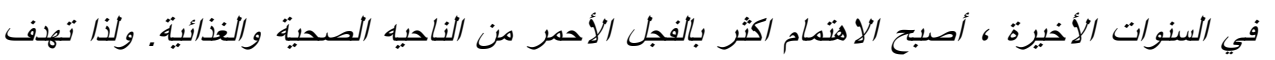

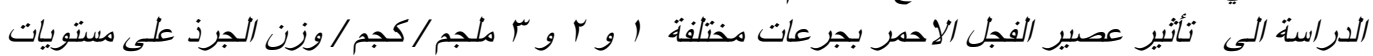

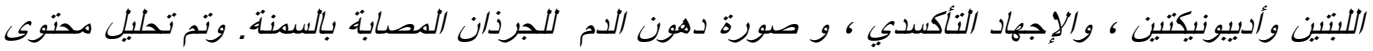

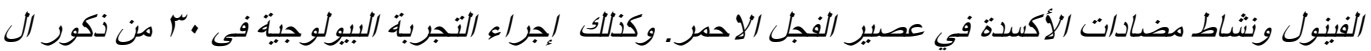

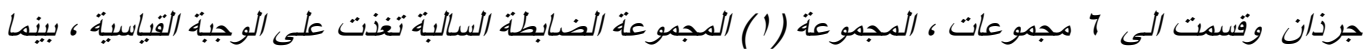

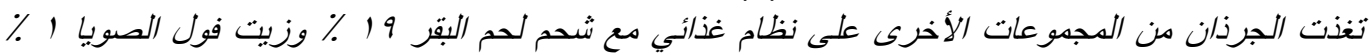

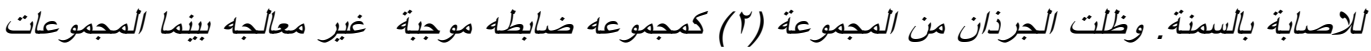

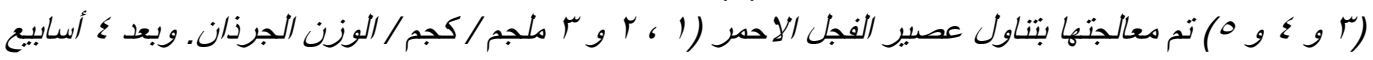

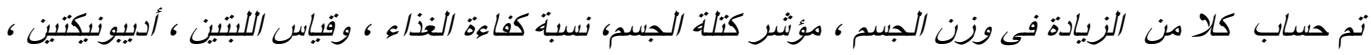

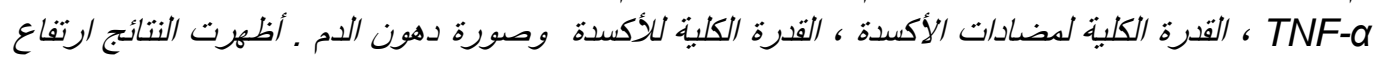

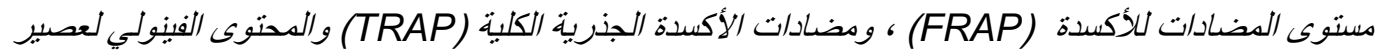
، الفجل الأحم. أظهرت مستويات عصبر الفجل الاحمر انخفاضًا كبيرًا في اللبتبن ، أدبيونيكتبن ،

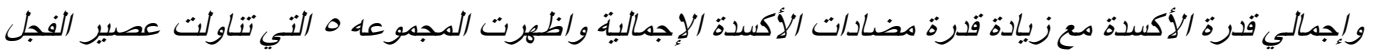

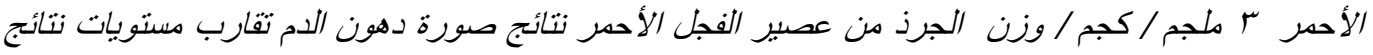

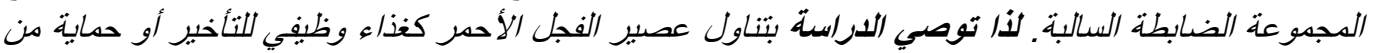
خطر الأنسجة الدهنبة و تحسن تحلبيل الدم. الكلمات المفتاحية: الأنسجة الدهنية ، الفجل الأحمر ، مضاد للالتهابات ، مؤشر كثلة الجسم. 